\title{
부산총회 결과와 의회의 역할
}

김 충 환 국회 외교통상통일위원회 위원장

\begin{tabular}{|l|}
\hline \multicolumn{1}{|c|}{ 목 차 } \\
I. 서론 \\
II. 한국과 개발협력 \\
III. 부산세계개발원조총회 결과문서의 주요내용 \\
IV. 부산총회 이후 성공적인 개발협력을 위한 의회의 역할 \\
V. 결론
\end{tabular}

\section{I. 서론}

부산세계개발원조총회가 11 월 29 일부터 12 월 1 일까지 부산에서 개최되었다. 총회가 열린 부산은 50 년 전에는 원조물자가 내리던 항구였지만, 이제는 세계 5 위의 무역항으로 원조의 성공가능성을 보여 주고 있다. 총회 기간 첫째날 파리선언의 이행과 향후 실천방안, 개발효과성 문제에 대한 토의가 이루 어졌으며, 둘째날에는 투명성 등 미래과제, 양성평등 특별세션, 남남협력 문제, 개발효과성을 높이기 위한 방안 등이 다루어졌다. 이를 토대로 셋째날인 12 월 1 일에는 향후 개발원조분야의 협력방향과 원 칙이 담긴 부산선언이 마련되었다. 아울러 부대행사도 50 여개가 열렸다. 부산총회에는 반기문 유엔사 무총장, 이명박 대통령, 폴 카가메 르완다 대통령, 앙헬 구리아 OECD 사무총장, 라니아 요르단 왕비 및 힐러리 클린턴 국무장관 등 10 여분의 최고위급 인사는 물론, 100 여명의 장관급 인사, 그리고 160 여 개국의 정부대표 등 3 천여 명이 참석한 역대 원조효과성에 대한 고위급 포럼 중 최대규모의 행사였다.

총 36 개항의 부산선언을 통해 새로운 개발협력체제의 기초가 마련되었다. 원조고위급포럼은 UN MDGs(Millennium Development Goals)를 달성하기 위한 노력의 일환으로 2002년 멕시코 몬테레이 회의의 합의에 따라 출범한 것이다. 부산총회는 그 간의 로마회의(2003), 파리회의(2005), 아크라회 의(2008)의 성과를 결산하는 자리이기도 하고, 새로운 개발협력 패러다임의 틀을 짜는 자리이기도 했다. 원조라는 수단을 넘어 결과인 개발문제에 포커스를 맞춤으로써 '개발'에 관련된 다양한 주체를 
인정한 것이다. 부산선언에서는 신흥개도국, 의회, 민간기업 및 NGO도 개발주체로 포괄되었다. 시 민사회 포럼, 의회포럼, 청소년포럼, 민간기업 포럼도 본 세션과 병행하여 개최해 다양한 의제를 수 렴하였다. 새로운 파트너쉽이 안착할 때까지 한국은 세계개발원조총회 개최국으로서 책임감을 가지 고 이행체제 문제를 다루는 데 많은 관심과 노력을 기울여야 할 것이다.

이 글은 다음과 같은 순서로 전개하려고 한다. 먼저 한국과 개발협력 문제의 관계를 기술할 것이 다. 한국의 경제발전에 대한 개발협력의 기여로부터 시작하여, 개발협력 레짐의 국제적, 국내적 실태 와 문제점을 설명한 다음 부산세계개발원조총회 결과문서를 소개하고, 의회의 관점에서 법적, 정책 적 차원에서 뒷받침 할 수 있는 역할을 모색해보고자 한다.

\section{II. 한국과 개발협력}

\section{1. 우리나라의 경제발전과 개발협력}

\section{가) 수원국으로서의 회고}

한국전쟁이 끝난 뒤 우리나라는 국민소득 67 불의 최빈국이었다. 한국 정부 수립 당시 1 인당 국민 소득은 50불에 불과했다. 당시 유엔한국재건단(United Nations Korea Reconstruction Agency, UNKRA)와 유엔식량기구(Food and Agricultural Organization, FAO)는 우리나라에 식량을 주로 지 원해주었다. 1961년부터 미국 국제개발처(United States Agency of Internaional Development, USAID)의 개발지원이 시작되었다. ${ }^{1)}$

해방이후부터 1999년까지 우리가 공여받은 총 원조액은 총 13,976 백만불로 추산되고 있다. 여기 에는 $\mathrm{NGO}$ 들의 지원액 1,200 백만불도 포함된 것이다. 우리나라에 가장 많은 지원을 한 나라는 미국 으로 5,542 백만불을 공여했으며, 이어서 일본이 5,052 백만불로 큰 규모의 지원을 해주었다. 그 외에 도 여러 나라가 우리나라의 재건을 지원하였는데, 독일 835백만불, CRIK(Civil Relief In Korea) 457백만불, 세계은행 143백만불, UNKRA(United Nations Korea Reconstruction Agency) 122백만 불, 아랍 제국 123 백만불, 프랑스 101백만불, 세계식량계획 99백만불, UNDP 69 백만불, UNTA(UN Regular Programme of Technical Assistance) 32백만불, 네덜란드 18백만불, UNICEF 14백만불, 호주 14 백만불, 덴마크 10 백만불, 벨기에 10 백만불, 영국 10 백만불, 캐나다 8 백만불, UNFPA9UN Fund for Population Activities) 8백만불, 스웨덴 8백만불, ADB 7백만불, ADF 6백만불, 이태리 6 백만불, 노르웨이 5 백만불, 스위스 5 백만불 등으로 열거해볼 수 있다.

1) 한국국제협력단, 『한국국제협력단 20년』(한국국제협력단, 2011), pp. 35-37. 
이와 같은 우리나라에 대한 국제사회의 지원 가운데 $55 \%$ 는 무상, 나머지 $45 \%$ 는 유상원조였다. 무 상원조는 주로 우리나라의 농업분야, 기술원조, 직업훈련 분야에 투여되었다. 1960년까지의 원조총 액 중 $42 \%$ 가 농업분야의 발전을 위해 공여된 것이다. 또한 기술원조로 4,643 명의 전문가를 초청하 고 20,784명의 우리인력이 해외훈련 및 연수를 받을 수 있었다. 직업훈련 면에서도 UNDP 등은 중앙 직업훈련원을 건립해주었다. 그밖에도 보건의료, 전력 및 통신 분야 등 매우 넓은 분야에서 외부의 지원을 받았다. 한편 유상원조, 즉 양허성 공공차관은 5,528 백만불에 달했다. 이 중 많은 부분이 경 제하부구조와 생산 부문에 공여되었다. 경제하부구조 부문에 전체의 $31.7 \%$ 에 이르는 1,753 백만불, 생산분야에 $21.3 \%$ 비중의 1,178 백만불이 유입된 것이다. 우리는 이처럼 기술재, 자본재 등 다양한 분야에 걸쳐 원조를 받았는데, 채무구제가 없었다는 특징이 있었다. 아래〈표-1〉은 시기별 우리나라 에 대한 원조 수원현황이다. 우리나라가 경제개발에 매진하던 1961년에서 1975년 사이에 가장많은 지원이 이루어졌음을 보여준다. ${ }^{2)}$

〈표-1〉시기별 수원현황

\begin{tabular}{c|c|c|c|c|c}
\hline 구 분 & $1945 \sim 1960$ & $1961 \sim 1975$ & $1976 \sim 199$ & $1991 \sim 1999$ & 합 계 \\
\hline 무 상 & $3,045.6$ & $1,999.0$ & 750.4 & $1,202.5$ & $6,997.5$ \\
\hline 유 상 & 52.3 & $1,942.4$ & $2,760.4$ & $1,023.7$ & $5,778.8$ \\
\hline 합 계 & $3,097.9$ & $3,941.4$ & $3,510.8$ & $2,226.2$ & $12,776.3$ \\
\hline
\end{tabular}

(단위 : 백만불)

1960년대 경제발전기 우리나라는 적극적인 개발계획을 토대로 다양한 국제개발협력사업을 추진했 다. 이전에는 국제사회의 원조계획에 따라 원조를 피동적으로 받아들여왔다면, 경제발전기에는 경제 개발계획을 위해 외부의 자원을 이용했다고 할 수 있을 것이다. 1961 년에 수립된 경제개발계획을 위 한 대외자원 683 백만불 중 426 백만불은 개발차관으로 충당한다는 계획이었다. 이를 위해 정상외교 와 각종 투자사절단이 파견되었다. 특기한 것은 미국, 일본, 독일 등 주요 공여국이 참가하는 대한국 제경제협의체(IECOK: International Economic Consultative for Korea)의 구성을 우리나라가 제안 했다는 것이다. 이에 따라 1 2년에 1 회 대한공여국과 기구들이 보다 효율적인 개발협력실시방안을 협의했다. 1966년 설립된 대한국제경제협의체는 1980년 초반까지 유지되었다. 이러한 한국의 적극 적 개발협력외교 하에서 제 1,2 차 경제개발계획 5 개년 계획이 시행되었던 것이다. 동 기간 중 우리나 라는 대외원조를 이용해 포항제철과 경부고속도로 건설 등의 프로젝트를 진행했다. 이를 통해 우리 나라는 저개발국으로서의 기술과 자본격차 문제를 극복하고, 경제성장의 토대를 닦았다.

2) 한국국제협력단, 『한국에 대한 개발원조와 협력 : 우리나라의 수원 규모와 분야, 효과사례 등에 관한 조사연구』(한국국 제협력단, 2004)를 참조하였음. 
1970년대 중반 이후부터는 우리나라에 대한 전체적인 원조규모도 줄어들어 갔다. 우리나라의 1 인 당 GNP가 520불을 넘어서면서 IDA차관공여대상국에서 벗어난 것이다. 또한 1975 년 12 월에는 대일 청구권 협정도 종결되었다. 나아가 우리 스스로도 투자자금 확보에 보다 선별적인 태도를 보였다. 과 도한 외채부담도 예민한 이슈로 부각되었기 때문이다.

\section{나) 공여국으로서의 전환}

한국이 공여국이 되기 위한 준비가 시작된 것은 1986년 대외경제협력기금 신설, 1991년 한국국제 협력단 설립을 즈음한 때이다. 80년대 후반 파푸아뉴기니를 위한 원조관련 회의에 옵저버로 참석하 게 된 것이었다. 또 우리나라는 1988년 $\mathrm{ADB}$ 공여대상국 리스트에서, 1995 년에는 세계은행의 공여대 상국 리스트에서, 2000년에는 $\mathrm{OECD}$ 수원국 리스트에서 제외되었다.

2010년 1월부터 우리나라는 DAC 회원국으로서의 활동을 시작했다. DAC 가입추진이 검토된 것은 2005년 11월 국무회의였다. 이후 ODA개선종합대책이 의결되는 등 선진공여국으로 탈바꿈하기 위한 준비작업들이 개시되었다. 2007년 7월과 2008년 8월의 국제개발협력위원회에서 2010년 DAC 가입 방침이 확인되었다. 2009년 1월 공식적으로 $\mathrm{DAC}$ 에 가입신청서를 제출했다. 2008년의 사전 특별검 토, 2009년 6월 DAC의 방문 실사, 11 월의 가입심사를 거쳐 한국의 가입안이 승인되었다. 이로써 원 조의 대상인 최빈개도국이었던 우리나라는 반세기 만에 극적으로 원조를 주는 나라가 되었다. 향후 우리나라는 현재 GNI 대비 $0.15 \%$ 수준의 $\mathrm{ODA}$ 를 $0.25 \%$ 수준까지 높여나갈 예정이다. 경제성장의 후발주자이던 우리나라는 이제 개발협력의 주역이 되어 새롭게 도약하고 있다.

\section{2. 전세계적 개발원조 현황}

국제원조체계를 살펴보면, IMF와 세계은행 중심(IBRD)의 개발원조 체제가 있다. 알다시피 이 기 관들은 브레튼우즈협정에 의해 설립된 기관들이다. 이들은 전후 서유럽국들과 일본의 급속한 경제부 흥으로 개도국 지원에 중점을 둘 수 있게 되었다. 1960년 9월 세계은행은 그 산하에 저소득 국가에 대한 경제개발과 생산성 향상을 돕기 위한 국제개발협력위원회(International Development Association, IDA)를 설립했다. 이를 통해 저소득국가에 대한 양허성 차관이 공여되었다. 1980년대 채무상환을 하지 못하는 개도국들이 늘어나는 시기 $\mathrm{IMF}$ 와 세계은행은 작은정부와 시장원리를 중심 으로 한 구조조정 정책을 제안하였다. ${ }^{3)}$

3) 이천우, "국제 공적개발원조의 신조류와 한국의 ODA정책," "산업정책연구』제24권, 제2호, pp. 782-786. 
1961년 OECD에 DAG(현재의 DAC에 해당)가 설치되었다. OECD의 전신은 유럽경제협력협의체 (OEEC: Organization for European Economic Cooperation)로서 유럽의 전후재건을 위한 기구였 다. 1996 년 미국과 캐나다가 참여하면서 $\mathrm{OEEC}$ 는 $\mathrm{OECD}$ 로 전환되었다. OECD 내의 원조국들은 각기 상이한 목적을 지니고 있었다. 미국은 냉전체제 하에서 안보를 증진시키고자 한 반면, 북유럽 국가들 은 개발 및 빈곤퇴치 자체를 중요시하였다. 영국과 프랑스 등은 옛 종주국으로서 구식민지를 관리하 고자 하였고, 일본은 태평양전쟁의 피해국들에게 사죄 성격을 지닌 원조를 제공하여야 했다. DAC는 이처럼 다양한 공여국들 간의 이해를 조정하고 공통의 구조를 마련하는 장이었다. 그래서 DAC는 공 적개발원조의 정의, 대상국 인정, 당위적 원조 자세, 공여국 간의 상호평가 등 개발협력문제에서의 규범을 정립하는데 역점을 두었다.

$\mathrm{UN}$ 에서도 1960년대 들어 개발협력 문제를 다루는 장이 마련되었다. 1964년 UNCTAD를 창설한 것이다. 1974년 UN특별총회는 신국제경제질서(New International Economic Order, NIEO)의 수립 을 위한 선언 및 행동계획을 개도국들의 의견을 반영하여 채택하였다. 본래 이 계획은 1974 년의 비 동맹 정상회의에서 논의되었던 것이다. 비동맹국가들은 1960 년대 '원조보다는 무역을'이란 문제에 대해서 논의하였었다. NIEO의 채택은 개도국들의 문제의식을 반영했다. 1970년대 비동맹노선의 강 화로 개도국들의 입김이 커졌기 때문이다.

2000년대에 들어와서는 IMF, OECD, UN 차원의 개발협력 노력이 통합된 형태를 띄게 되었다. 그 배경은 빈곤퇴치전략의 발전 및 원조문제의 부활과 맞닿아 있었다. 80년대를 거쳐 90 년대 들어와 선 진국 사회에서는 원조에 대한 피로감이 팽배해졌다. USAID 폐지론까지 거론되었던 것이다. 이러한 배경에서 성장촉진만으로는 빈곤퇴치가 어렵다고 보고, 빈곤층을 위한 교육, 보건, 영양, 인구계획을 중시해야 한다는 내용의 세계은행 '세계개발보고서 1990'의 제안이 주목을 받았다. 1996년 OECD $\mathrm{DAC}$ 도 그에 기반하여 '신개발전략'을 내놓아 원조의 고유한 필요성을 재강조하였다. 누적채무 문제, 원조의 특정국 집중으로 인한 낭비를 해소해야 함을 지적하고, 원조는 다른 지원으로 대체할 수 없는 고유한 역할을 하기 때문에 포기되어서는 안된다는 점을 강조하였다. 이러한 상황을 바탕으로 UN 새천년특별총회에서 '밀레니엄 선언문’이 발표되었다.4) 전 세계가 2015년까지 달성할 8개 분야 21 개 과제를 설정한 것이다. ${ }^{5)}$ 각 기관은 조정과 협의과정을 거쳐 MDGs의 달성을 위한 개발재원 확보, 원 조의 효과성, 다자개발기구의 일관성 등의 노력을 진행하고 있다.

4) 같은 해 세계은행도 세계개발보고서의 주제를 빈곤퇴치로 설정했고, IMF도 수원국의 주체성을 존중하는 원조를 표방했다.

5) 그 내용은 다음과 같다. (1) 극단적인 빈곤과 기아를 절반으로 줄인다. (2) 보편적인 초등교육을 실현한다. (3) 여성의 권 한을 강화하고 남녀평등을 촉진한다. (4) 5 세 이하 사망률을 $2 / 3$ 로 줄인다. (5) 산모 사망률을 $3 / 4$ 줄인다. (6) HIV/AIDS, 말라리아 등 각종 질병의 확산을 억제한다. (7) 지속가능한 환경을 확보한다. (8) 원조, 무역, 외채탕감 등의 목표와 함께 개발을 위한 전 지구적 파트너쉽을 만든다. 
현재의 개발협력 체제를 살펴보면, 2010 년 기존공여국인 DAC 회원국들은 총 1287.3 억불의 ODA 를 집행하고 있다. DAC 회원국 중에서 가장 공여를 많이 하는 국가는 301.5 억불을 공여하는 미국이 다. 그에 이어서는 영국(137.6억불), 프랑스(129.1억불), 독일(127.2억불), 네덜란드(63.5억불), 스페 인(59.2억불), 캐나다(51.3억불), 노르웨이(45.8억불), 스웨덴( 45.3 억불), 호주( 38.5 억불), 이탈리아 (31.1억불), 벨기에(30억불), 덴마크(28.7억불), 스위스(23억불), 핀란드(13.4억불), 오스트리아(12억 불), 한국(11.7억불), 아일랜드(9억불), 포르투갈(6.5억불), 그리스(5억불), 룩셈부르크(4억불), 뉴질 랜드(3.5억불) 순이 된다. 원조방법 상 DAC 회원국의 유상원조는 $12.6 \%$, 비구속성 원조는 $86.5 \%$ 수 준이다. 2009년 기준 양자지원 83,602 백만불 중 기술협력이 17,546 백만불로 가장 높은 비중을 차지 하고 있으며, 인도적 지원이 8,633백만불로 두 번째로 높은 비중을 보이고 있다.

그러나 이러한 개발협력 체제 밖의 새로운 원조흐름도 성장하고 있다. 무엇보다도 브릭스 등 신흥 개도국의 부상 때문이다. 비DAC 회원국인 이들에 의한 ODA활동도 늘어나고 있는 것이다. 신흥개도 국은 매년 140 억불의 원조를 집행하고 있으며, 그 규모도 2015년까지 26 억불로 성장할 것으로 전망 되고 있다. 중국의 예를 보면, 그 ODA액이 2000년 5.54억불에서 2006년 10.33억불, 2007년 14.67 억불, 2008년 18억불, 2009년 19.5억불로 지속적으로 늘어나고 있는 추세이다. 국제적으로 원조의 범주에 속하지 않는 경제협력자금을 모두 포함할 경우 250 억불에 상당한다는 관측도 있다. ${ }^{6)}$ 뿐만아 니라 사적 개발원조도 최소 520 억불에 달하며, 개인 $\mathrm{NGO}$ 및 재단도 10 억불을 넘는 경우가 있다. 나 아가 개도국에의 민간자금 유입도 총 2221.7 억불로 $\mathrm{ODA}$ 총액을 뛰어넘는다. 이처럼 기부자 및 공여 기관이 확산됨에 따라 새로운 개발협력 패러다임이 필요하다는 지적이 제기되고 있다.

덧붙여 MDGs 이외에도 기후변화, 식량안보, 금융안정성, 무역, 에너지 접근성 문제도 개발분야가 다루어야 할 문제로 대두되고 있다.

\section{3. 한국의 개발협력정책 현황}

우리나라의 개발협력 분야는 2000년대 초반을 거치면서 확대일로를 걷고 있다. 무엇보다도 2003 년 이후 이라크와 아프간 지원, 다자개발은행 출연·출자 증가 등으로 ODA 규모가 급격히 증가한 것 이다. 이어 2005년 국제개발협력위원회가 설치되었고, 2009년 12 월에는 국제개발협력기본법이 제정 되었다. 2010 년 1 월 DAC 회원국으로서의 활동이 시작되었다. 이에 걸맞는 원조역량 배양의 필요성 이 제기됨에 따라 2010년 10월에는 ODA 선진화 방안이 마련되기에 이른다. 아래에서는 이러한 우리 나라의 개발협력 분야의 전체적 틀을 짚어보고자 한다.

6) 권율, 박수경, 『중국의 대외원조정책과 추진과제』(대외경제정책연구원, 2010), pp. 57-58. 


\section{〈표-2〉우리나라의 총 ODA 지원액}

\begin{tabular}{c|c|c|c|c|c|c|c|c}
\hline 구분 & 2003년 & 2004년 & 2005년 & 2006년 & 2007년 & 2008년 & 2009년 & 2010년 \\
\hline \hline 액수 & 366 & 423 & 752 & 455 & 696 & 802 & 816 & 1,168 \\
\hline
\end{tabular}

우리나라의 유무상 원조에 있어 무상원조는 한국국제협력단이, 유상원조는 수출입은행의 대외경 제협력기금이 주로 담당하고 있다. 시기적으로 먼저 정비된 것은 유상원조 관련 제도였다. 대외경제 협력기금 업무가 수출입은행에 1987년 6월 수탁된 것이다. 그에 따라 대외경제협력기금은 개도국의 경제개발에 필요한 장기저리 차관을 제공하고, 개도국의 산업발전 및 경제안정, 대외경제협력촉진을 그 목적으로 하여 운용되고 있다. 또한 한국국제협력단은 1991년 설립되었다. 1982년부터 정부 각 부처에서 산발적으로 추진해오던 ODA사업을 일원화하려는 것이 설립의 취지였다고 할 것이다. 국제 협력단의 원조이념은 개도국과의 우호협력 및 상호교류, 경제사회발전 증진 등이다. ${ }^{7}$

2008년 기준 우리나라의 ODA 규모는 GNI 대비 0.12\% 수준이며, 비구속성 비율은 $35.8 \%$ 이다. $\mathrm{ODA}$ 선진화 방안에서 따르면, 2015 년까지 ODA 규모는 $0.25 \%$ 로, 비구속성 원조 비중을 $75 \%$ 까지 확 대하도록 되어 있다.

우선 유상원조 부문을 살펴보면, 대외경제협력기금의 승인액은 현재까지 총 7 조 1,830 억원에 달한 다. ${ }^{8)}$ 그 지원을 받은 나라들은 46 개국이다. 베트남이 총 1 조 4947 억원으로 가장 많은 금액을 승인받 았고, 그에 이어서 인도네시아(5,799억원), 방글라데시(5,426억원), 스리랑카(4,956억원), 필리핀 (3,795억원), 캄보디아(3,201억원), 탄자니아(2,554억원), 앙골라(2,514억원), 중국(2,335억원) 등의 순서를 보인다. 지원분야는 승인액 기준으로 교통분야가 2 조 5 천억원 가량 지원받았으며, 수자원분 야에 약 1 조 2 천억원, 에너지분야 약 8 천억원, 보건분야 약 7 천억원, 교육분야 약 6 천 900 억원, 통신 분야 약 6 천 100 억원, 공공행정분야 3 천 200 억원이 지원되었다.

수출입은행은 집행규모를 확대하려고 한다. 2011년 집행목표를 2010 년 대비 47.3\% 증가한 6,047 억원으로 잡고 있다. 특히 자원부국에 대한 지원 확대, 녹색금융과의 연계사업 발굴 및 국제개발금융 기관 협조 융자 활용, 민관협력방식 활용, 프로그램차관 도입 등 지원방식을 다양화할 계획이다. 이 를 통해 국가전략분야에 대한 지원을 확대한다는 것이다.

한편 한국 국제협력단은 52개국, 3 개 지역기구에 무상원조를 시행하고 있다. 2012 년 예산안 기준

7) 한국국제협력단, 『한국국제협력단 20년』(한국국제협력단, 2011), p. 52.

8) 차관은 장기저리로 이자율 2.5 5\%로 제공되며, 기금조성 누계는 2011년 말 현재 2조 9천억원이다. 
공여대상국은 아시아 15 개국 및 3 개 지역기구(PIF, ASEAN, SAARC), 아프리카 19개국, 중남미 10 개국, 중동 및 CIS지역 8개국이다. 총 2,359억원의 국가별 예산프로그램 중 상위 10 개국에 대한 예 산규모를 살펴보면, 아프가니스탄 221억원, 필리핀 121 억원, 베트남 120 억원, 캄보디아 112 억원, $\mathrm{DR}$ 콩고 100 억원, 파키스탄 96 억원, 이라크 82 억원, 네팔 78 억원, 인도네시아 71 억원, 몽골 66 억원으로 나타나고 있다. 나라별 평균지원액은 약 41.1 억원 정도이다. ${ }^{9)}$

국제협력단의 분야별 지원실적을 통해보면, 교육과 보건, 그리고 행정제도 부문이 각기 $15.3 \%$, $16.5 \%, 15.3 \%$ 를 차지하고 있다. 농어촌개발분야는 그 비중이 최근 들어 $11 \%$ 로 증가하면서 중요성이 부각되고 있다. 교육분야는 빈곤감소의 중점 분야로 지원되고 있다. 직업훈련에 1 억 2,464 만불, 기 초교육에 6,937만불이 쓰였다. 특히 이라크와 아프가니스탄에서는 재난복구 차원에서 대규모 기초교 육을 지원하고 있다. 또한 보건분야는 관련 $\mathrm{MDGs}$ 목표가 다수로 아동사망률 감소, 모성보건 증진, 에이즈/말라리아 등 질병 퇴치에 두루 관련돼 있다. 우리나라는 아시아(35\%), 중동(20\%), 아프리카 (17\%), 중남미(15\%) 순으로 공여를 배분해 왔으며, 해외봉사단 983 명, 의료단 총 72 명을 파견하고 있다. 혁신재원인 빈곤퇴치기여금도 콩코 모기장 보급사업 등에 쓰여졌다. 행정제도 분야는 총 54 건 의 프로젝트가 시행되었으며, 정보통신 시스템 개선이 주를 이룬다. 마지막으로 농어촌개발 분야는 농업생산성 향상, 농축수산물 시장 접근성 제고, 생활환경 개선 및 소득 증대의 3 대 목표를 중심으로 추진된다. 우리나라의 개발경험 전파라는 차원에서 주목을 받고 있다. 1991년 설립당시 137 만불이었 던 관련 예산이 2010년 기준 4730 만불에 달하고 있다.

이와 함께 국제협력단은 월드프렌즈코리아(World Friend Korea)라는 통합 브랜드 하에 해외봉사 단을 파견하고 있다. 2010년 외교부, 교과부 등 4개 부처, 6 개 기관의 봉사단 사업이 단일 브랜드 하 에 통합된 것이다. 1991 년 37 명의 봉사단이 최초로 파견된 이래, 2010 년까지 61 개국에 7,762 명의 단 원 파견되었다. 2004년 봉사단 파견규모는 220 명에서 720 명으로, 2008년 다시 1,000명으로 증가했 다. 파견분야별로는 교육에 $41.2 \%$, 정보통신 $11.8 \%$, 농어촌 개발 및 보건의료에 각각 약 $10 \%$, 행정 제도 분야에 $8.6 \%$ 에 상당하는 봉사단이 파견되어 활동 중이다.

\section{4. 개발협력의 문제점과 성공을 위한 조건}

단순한 원조공여만으로는 빈국의 발전에 도움이 되지 않는다. 최빈개도국에 대한 원조액은 2000 년의 약 120 억불에서 2005년 259억불, 2009년 401억불로 증가되어 왔다. 그럼에도 불구하고 1980년대 중반 이후 이 국가들의 경제구조에서 제조업이 차지하는 비중은 거의 변화가 없다. 1987 년에도 2008년에도 제 조업의 비중은 총생산의 약 $10 \%$ 로 일정하다는 것이다. 다만, 광업과 건설업이 확대되었을 뿐이다. 세계

9) 2012년 예산안 총액은 2011년에 비교할 때 29.3억원 감소해 있는 상태이다. 2012년도 KOICA 예산안 설명자료를 참조하였음. 
경제위기 이후 최빈국의 경제성장률이 낮아지면서 발전전망도 밝지 못하다. 최빈국의 2010년 경제성장률 이 2001 2008년 사이의 7.1\%에 못미치는 5.7\%에 그치고 있다. 더욱이 인구증가율이 높은 특성 때문에 1 인당 GDP 증가율은 $3.4 \%$ 에 불과했다. 이러한 추세는 2016년까지 지속될 것으로 추정되고 있다. ${ }^{10)}$

개발협력의 성공을 위한 첫 번째 조건은 무엇보다도 수원국의 자립의지다. 제프리 삭스는 개발의 실 패이유로 빈곤의 함정, 자연지리, 재정적 함정, 통치구조, 문화, 지정학, 부족한 혁신, 인구구조 등을 들 었다. 그 중에서 개발을 달성하기 위해 극복해야 할 가장 중요한 문제로 든 것이 빈곤의 함정이다. 빈곤 이 아주 극단적인 경우 미래를 위한 준비에 중점을 둘 수 없다는 것이다. 중하위소득국의 저축율이 약 $38 \%$ 인 반면, 최저개발국의 저축율은 $10 \%$ 에 불과하다. 이 때문에 이들 나라에서는 발전을 위한 투자를 하지 못하고 있는 상태다. 빈곤의 함정을 벗어나는 데는 자립의지가 중요하다. 발전노력을 일단 시작하 면, 자본축적, 전문화, 선진기술 유입 등 일련의 수순에 따라 자연적으로 개발과정이 전개될 수 있다. ${ }^{11)}$

또한 민주주의의 발전도 필요하다. 전제적 통치 하에서의 원조는 부패를 악화시킨다. 정부가 자유 롭게 쓸 수 있는 돈을 제공하는 셈이 되기 때문이다. 강화된 전제적 통치로 오히려 법치주의, 시민적 자유 등이 억압되고, 국내외 투자감소, 경제성장율 하강, 빈곤증가 등의 현상이 연쇄적으로 일어나기 도 한다. 성공적인 개발을 위해서는 정치적 책임체제의 발전 역시 필요한 까닭이다.

공여국의 원조목적도 자선(charity) 수준을 벗어나야 한다. 구호목적의 사업으로는 발전을 달성하 기가 어렵다. 글렌 허버드 등도 전쟁으로 폐허가 된 유럽을 부흥시킨 것은 마샬플랜이지 구호사업이 아니었다고 지적해 왔다. ${ }^{12)} \mathrm{UN} \mathrm{MDGs인} \mathrm{빈곤퇴치를} \mathrm{이루는} \mathrm{근본적} \mathrm{해법도} \mathrm{개도국} \mathrm{자체의} \mathrm{경제사회}$ 적 발전에 있다.

또한 비구속성 원조도 대부분 공여국 자국기업을 통해 이루어지고 있다. DAC 회원국 평균 비구속 성 원조 비율은 약 $87 \%$ 이다. 그 가운데 2008년 기준 비구속성 원조의 $62 \%$ 가 공여국 내의 기업을 통 한 것이었다. $\mathrm{OECD}$ 국가의 기업을 통한 경우도 $12 \%$ 로, 개도국과 최빈국을 통한 경우는 $26 \%$ 에 불과 했다. 이는 비구속성 원조 증진의 목적과 배치되는 결과이다. 그 목적은 본래 수원국의 주인의식을 증진하고 비용을 절감하는 데 있기 때문이다. 선진국 내의 관련기업의 경우 국제경쟁입찰에서의 경 쟁력이 높고, 자국 행정절차에 관한 노하우가 마련되어 있다. 따라서 실질적 원조 구속화의 현상이 나타나고 있는 것이다. 또한 수원국이 자립할 수 있도록 도와주는 촉진적 개발원조가 필요한 시점이 다. 우리나라의 경제개발도 대외원조 자금을 통해 추진할 수 있었던 것이다. 수혜국이라는 점을 명심 하면서 개도국 및 빈국을 돕기 위한 노력을 경주해야 한다. 60 년대 세계 개발협력 체제가 개도국 지

10) UNCTAD, “The Least Developed Countries Report 2011"(UN, 2011).

11 ) 제프리 D. 삭스 지음, 김현구 옮김, 『빈곤의 종말』(21세기북스, 2000), pp. 86-115.

12) 글렌 허버드, 윌리엄 던컨 지음, 조혜연 옮김, 『원조의 덫』(비지니스맵, 2010)을 참조하였음. 
원에 중점을 두던 때에 우리는 혜택을 받았던 것이다. 제 2 , 제 3 의 한국을 만들기 위해 수원국의 개발 을 위해 필요한 자원과 경험을 나누는 데 중점을 두어야 할 것이다.

\section{III. 부산세계개발원조총회 결과문서의 주요내용}

부산세계개발원조총회의 결과문서는 전문, 변화 실현과제, 효과적 개발협력, 포스트 부산 이행체 제의 네 가지 부문으로 구분되어 작성되어 있다. 아래에서는 각 부문을 중심으로 부산총회 결과문서 를 소개하고자 한다.

\section{1. 전문}

먼저 부산선언은 도입부부터 개발주체의 다양화를 표방하고 있다. 선진국 및 개도국만이 아니라 다자·양자기구, 그리고 시민사회, 의회, 지방 및 지역기구의 대표들을 모임의 주체로 하고 있다. 이 는 2003년 로마선언의 도입부가 다자, 양자 개발기구, IMF, 파트너국가들의 회합을 설명하는 데에서 시작하였던 것과 대비되는 것이라고 하겠다. 파리선언 역시 시민사회와 의회 등을 하나의 개발주체 로서 설정하지 않았었다. 이어 부산선언은 이러한 다양한 개발주체들이 ‘새로운 파트너쉽’에 의해 결 합되었음을 강조하고 있다. 다만 '공유된 원칙과 공통의 목적, 그리고 서로 다른 공약' 위에 이러한 파트너쉽이 기초하고 있다고 하여 다양한 주체들의 공약수준은 다를 수 있음을 드러내고 있다. ${ }^{13)}$

남남협력 남북협력의 차별성을 인정하였다. 공통의 목적과 공유하는 원칙이 있음을 강조하였지만, 각국은 각자의 상황에 기초해서 효과적 협력을 지원한다는 것이다. 또한 부산선언의 내용은 남남협 력 문제에 대해서는 '자발적 기초' 상에서 적용된다고 명시하고 있다. 이는 중국과 인도 등의 남남협 력 활동이 부산선언에 포함되지만 그 완전한 이행을 약속하지는 않았음을 나타낸다.

다음으로는 지구적 개발목표를 확인하고 있다. UN MDGs의 개발목적이 갖는 보편성을 인정하면 서 지속가능한 개발의 시급성을 강조하고 있다. 인권, 민주주의, 선정(善政, good governance) 증진 및 취약국 및 분쟁파급국가 지원의 중요성도 언급되었다.

국제사회의 개발협력의 새로운 과제도 제시하였다. 빈곤, 불평등, 기아문제 만이 아니라 새로운 문제도 다루기 위한 노력이 필요하다는 것이다. 그에 따라 전염병, 기후변화, 경기하강, 식량 및 유

13) 제8항을 보면, 민간주체들에 대해서도 공통의 원칙이 적용되는 방식은 다를 수 있음이 확인되어 있다. 
가 위기, 분쟁, 취약성, 자연재해에 대한 취약성(vulnerability) 등이 개발협력의 도전과제로 제시되 었다. 이는 2003년 로마선언 전문의 개발과제로 빈곤퇴치, 일관적 경제성장, 지속적 개발증진만이 언급되었던 바와 비교해볼 수 있다.

또한 개발협력 체제의 복잡성을 담아낼 수 있는 파트너쉽의 문제를 다루었다. 기존의 남북협력을 남남 협력, 삼각협력, 민관협력 등 다양한 원조방식이 보완할 수 있다는 것이다. 이러한 연장선에서 제 7 항과 8 항은 새로운 글로벌 파트너쉽을 결성하려는 의지와 다양한 개발주체와의 협력용의를 선언하고 있다.

이어 제 9 항에서는 지속가능한 개발을 참가주체들의 공약과 효과적 개발의 목표로 상정하고 있다. 효과적 협력이 개발자원의 감소를 초래해서는 안된다는 것이다. 또한 수원국들의 원조에 대한 의존 도를 감소시키는 것을 지향하고 있다. 이러한 자립과정에서 수원국이 국제투자와 무역 기회를 최대 한 활용하고 국내 자본시장을 확대할 수 있도록 전체 공공정책의 상호의존성과 일관성을 확보하도록 하고 있다. 제 10 항은 민간투자, 무역을 위한 원조, 비양허성 공공차관 및 기후변화 재원 등 다양한 개발재원들을 활성화하는 문제도 고려하고 있다.

그 다음으로는 공통의 원칙과 공통행동이 이어진다. 공통의 원칙은 수원국의 주인의식, (빈곤퇴치, 불평등 감소, 지속가능한 개발, 개도국 역량개발, 수원국의 우선순위에 대한)결과중심, 포괄적 개발 파트너쉽, 투명성 및 상호책임성이다. 공통행동은 개발정책과 프로세스에서 민주적 주인의식의 심화. 확대·운용, (결과중심의 관리개선, 모니터링, 진전상황 평가 및 지원규모 확대 등)구체적이고 지속가 능한 개발성과를 위한 노력 강화, 남남/삼각협력에 대한 지원 확대, 다양한 개발재원과 활동의 촉매 적 역할 지원으로 제시됐다.

\section{2. 변화의 실현과제}

\section{가) 공통의 원칙과 상이한 공약 하에서의 새로운 개발주체 포함}

원조효과성 심화의 부분에서는 새로운 개발주체의 포함문제가 가장 먼저 거론되고 있다. 신흥개도 국들이 남남협력의 주요 공여국이 되고 있다는 것이다. 또 부산선언이 파리선언과 아크라행동계획과 달리 신흥개도국들이 참여하는 보다 새롭고 포괄적인 개발의제를 형성하였다는 점을 언급하였다. 그 틀안에서 시민사회와 사적영역 및 다른 개발주체도 포섭된 것이다.

\section{나) 원조효과성 심화}

이 부분에서 가장 먼저 언급된 내용은 '주인의식, 성과 및 책임성 강화'의 부문이다. 제목과 달리 
성과, 책임성, 주인의식의 순서로 거론된다.

\section{1) 주인의식, 성과 및 책임성 강화}

개발성과 관련 내용이 우선적으로 설명된다. 수원국 주도, 수원국 수준의 성과 프레임과 플렛폼이 모든 관련 개발주체의 성과 측정에 적용되도록 하고 있다. 이는 수원국의 목적과 개발우선순위로부 터 얻어진 성과지표 등에 기초하게 된다(18-b). 또한 통계능력을 강화하기 위한 글로벌 행동계획(a Global Action Plan)을 이행하기로 합의하였다. 영향평가, 성과중심의 공적부문 관리 등을 위한 것 이다(18-c). 아크라행동계획에 의하여 비구속성 원조 감소노력도 가속화하고 2012년 원조 비구속화 를 위한 달성계획을 점검하기로 하였다.(18-e).

나아가 수원국의 시스템의 활용도도 높이기로 하였다. 수원국 시스템을 공적영역이 관리하는 활동 에 대한 개발협력의 기본방식으로 활용하기로 한 것이다. 다만 그(수원국 시스템)에 대한 진단결과를 기초로 공여국이 수원국 시스템의 활용 범위를 결정하도록 하였다. 수원국 시스템을 사용하지 않는 경우에는 사유를 설명하고, 개선방안을 수원국 정부와 논의해야 한다.

또한 양성평등 문제에 책임성 차원의 중요성을 부여하고 있다. 공적지출이 남성과 여성 모두에게 적절히 혜택을 줄 수 있도록 배분되도록 하고, 양성평등 및 여성 역량강화 지표 등을 국제적 및 지역 적 공약에 근거하여 책무성 체계에 통합하도록 하였다. 나아가 평화군축 및 국가재건 과정에서도 양 성평등 및 여성 역량강화의 문제를 다루도록 하였다.

다음은 민주적 주인의식을 보장하는 데서 의회 및 지방정부의 역할을 중시하고 있다. 무엇보다도 개발과정의 감독에 관한 의회의 역할을 강조하였다. 의회의 역량개발 등의 지원을 통해서 의회가 개 발과정 감시의 역할을 강화할 수 있도록 해야 한다는 것이다. 충분한 자원과 명확한 실행계획으로 뒷 받침되어야 함도 강조되었다. (파리선언의 의회 관련 내용은 개도국 정부가 정책형성 차원에서 의회 와 시민에 대한 관여를 높여야 한다고 기술되었던 것이었다. 그와 비교하면, 부산선언에서는 개발과 정에서 의회가 가질 역할이 보다 구체화되었다.) 덧붙여 지방정부의 책무성과 참여를 제고하여 이들 이 단순한 서비스 전달 이상의 역할을 확보하도록 하였다.

\section{2) 투명하고 책임있는 협력}

투명하고 책임있는 협력을 위해서는 공적자금 개발활동에 관한 전체 정보를 공개하도록 했다. 공 개정보의 범주에는 개발활동에 관련된 재원, 계약조건, 개발성과 및 기여도 등이 포함된다(23-a). 또한 수원국 차원에서는 이해관계자들이 의사결정에 활용할 수 있도록 투명한 공적자금 관리 및 원 
조정보 시스템을 구축하도록 하였다(23-b). 전자공개를 위한 공통표준은 $\mathrm{OECD} \mathrm{DAC} \mathrm{통계보고서와}$ IATI(International Aid Transparency Initiative) 방식을 고려하여 마련될 것이다. 2012년 12월까 지 표준방식을 합의하고, 각자 동 표준의 시행일정을 발표할 예정이다. 2015년까지 표준공개 방식의 전면 이행이 목표이다(23-c).

그리고 개발협력의 예측가능성을 아크라이행계획대로 이행하기로 했다. 3 개년 혹은 5 개년의 향후 지출/이행계획을 제공하기로 한 것이다. 아크라이행계획 참가국들은 필요한 경우 개혁도 추진하면서 이러한 약속을 2013년까지 이행해야 한다. 참고로 아크라이행계획에서는 공여국들이 '지금부터' 다 년간 계획을 수원국에 제공하도록 했었다. 아크라계획의 '지금부터(Beginning Now)'에 비하면 부산 선언의 약속이행 결의는 다소 온건하다 할 수 있다.

덧붙여 개도국이 협의와 조정과정을 주도하여야 함을 강조하였다. 개발주체의 다양성을 관리하여 야 한다는 것이다. 개발협력 제공자가 늘어남에 따라 분절화 및 원조채널의 과도한 확산 위험도 대처 되어야 한다. 그에 따라 2013년까지 (분업, 프로그램 중심의 접근, 공동 프로그램 및 위임협력 등) 수원국 주도의 협의체를 적극적으로 활용하자는 계획이 제시되었다(25-a). 2012년까지 다자기구, 글로벌 펀드 및 프로그램 등 다자협력 채널의 지나친 확산을 막기 위한 가이드라인도 마련하기로 했 다. 뿐만아니라 원조소외국(불충분한 지원을 받는 국가들)의 문제도 적극 대처하는 내용도 담겼다. 2012년까지 모든 개발재원을 포함해 행동 방향의 원칙이 합의될 것이다.

\section{3) 취약, 분쟁 상황에서의 지속가능한 개발과 재난상황에서의 복원력 강화 등}

부산선언은 취약국 문제해결을 위한 공동의 노력도 강조하였다. 취약국이 MDGs 달성과 동떨어져 있다는 것이다. 평화구축 및 국가건설 목표(PGSs, The Peacebuilding and Statebuilding Goals)를 취약국 등에서의 MDGs 달성노력에 활용하기로 하였다. ${ }^{14)}$ 그와 함께 취약국이 주도하는 새로운 관 여방식에 중점을 두고, 재원의 효과적 활용 및 결과중심 접근을 통한 상호신뢰도 강화하기로 하였다.

아울러 저개발 도서국을 위한의 지속가능한 개발은 (자연재해 등에 대한) 복원력 제고와 위기 감 소를 필요로 함을 지적하고 있다. 이 국가들은 복원력과 재난관리 조치를 자신들의 정책과 전략에 포 함해야 한다는 것이다. 또한 충격방지 인프라와 사회보호시스템에 대한 투자협력 제고와 재해관리를 위한 자원, 기술제공 등의 지원도 확대하기로 하였다.

14) PGSs는 (1) 포괄적인 정치적 합의와 과정, 그리고 포괄적인 정치적 대화의 촉진, (2) 기본적인 안전과 보안을 구축, 강화, (3) 평화적인 갈등해결과 정의에 대한 접근을 달성, (4) 서비스 전달을 촉진시키기 위하여 효과적이고 책임 있는 정부 기관들을 개발, (5) 지속가능한 생계, 고용, 그리고 효과적인 천연자원의 관리를 포함한, 포괄적인 경제 발전을 위한 기 반을 마련, (6) 화해와 평화적 공존을 위한 사회적 역량을 개발, (7) 지역적 안정성과 협력을 조성하는 등의 내용을 담는 다. 권역주, “취약국가의 이해 : INCAF와 국제협력 기구의 논의를 중심으로," 『국제개발협력』2010년 제3호 참조. 


\section{3. 개발효과성의 강조}

\section{가) 효과적 제도 및 정책}

수원국 정부 주도의 프레임워크가 강조되었다. 그 안에서 개발이 강력하고, 지속가능하며 포괄적 인 성장에 의해 추진되고, 수원국의 예산이 갖는 개발재원으로서의 역할이 주목되며, 효과적 국가기 관은 자국의 개혁을 설계/이행한다. 외부의 원조 역시 개발을 촉진할 수 있는 방식으로 공여되어야 한다(제28항). 수원국의 효율적 제도와 정책은 지속가능한 개발을 위해 필수적인 것으로 강조됐다.

\section{나) 남남협력 및 삼각협력}

부산선언은 지속가능한 개발 논의가 지식 및 발전경험 공유 차원에서 남남협력 및 삼각협력에까지 확대될 수 있다고 규정하고 있다. 각 국의 맥락에 부합하는 효과적이고 자체적인 해법을 발전시켜 서 비스 전달 및 접근법을 변형시킬 수 있다는 것이다(30). 그리고 남남협력이 다른 수원활동을 저해하 지 않아야 함을 강조하고 있다. 이러한 전제 하에서 여러 형태의 재원과 전문성이 교환되는 남남협력 의 형태를 인정한 것이다. 개발협력에 대한 삼각협력, 기존의 남남협력 및 삼각협력, 남남협력 주체 간의 지식교환, 상호학습과 조정 네트워크 독려, 지방·중앙정부의 역량 강화 등을 통해서 지식과 상 호학습을 강화시켜가겠다는 방향을 제시한다.

\section{다) 민간분야}

민간분야의 역할은 혁신촉진, 소득과 고용 증대, 국내 자원활용 등의 부문에서 비중을 갖는 것으 로 제시된다. 먼저 재계 및 노조 등과의 협력이 언급된다. 민간투자를 위한 법적, 규제적, 행정적 환 경 개선의 부문에서, 그리고 건전한 정책과 규제환경 보장 차원에서 이들과의 협력을 강화하겠다는 바가 천명된 것이다.(32-a). 다음으로 지속가능한 발전과 빈곤퇴치를 위한 전략 및 정책 개발. 이행 의 과정에 대한 민간의 참여도 가능해야 한다는 원칙이 명시되었다(30-b). 민간재원 조달을 위한 혁 신재원의 개발(32-c)과 “무역을 위한 원조”의 증진과 시장실패 해소, 자본시장 접근성 강화 등이 언 급되었다 (32-d). 이는 향후 과제를 설명한 대목으로 읽힌다. 아울러 민간과 공적부문의 대표를 동시 에 초대해 개발과 사업 성과가 서로 서로 강화하는 방식을 모색하기로 하였다(32-e).

\section{라) 부패척결과 불법적 흐름의 해결}

부패 문제에 대한 조항도 삽입되었다. 개발성과, 개발재원, 거버넌스, 인간안보, 범죄, 분쟁, 취약 성 면에서 부패가 갖는 부정적인 영향을 지적하고, 유엔반부패협약 및 $\mathrm{OECD}$ 뇌물방지협약에 의거해 부패를 척결하기 위한 노력을 강화한다는 방향성이 설명되었다. 이행사항으로는 부패척결을 위한 각 
자의 공약완수가 요청되었다. 뿐만아니라 불법자금 대처를 위한 개별적 노력의 강화도 언급되었다. 불법자금 척결을 위한 조치에는 효과적인 국제협력을 위한 관련법 제정 등을 포함해 각국 간의 유기 적 대응 능력을 제고시키고자 하는 의도를 보였다.

\section{마) 기후변화 재원}

기후변화 재원의 대폭적인 증대가 초래할 문제에 대비해 일관성, 투명성 및 예측가능성을 증진시키 기 위한 노력도 언급되었다. 개도국의 기후변화 정책과 계획을 지속적으로 지원하고, 이것이 수원국시 스템을 통해 투명한 방식으로 조달·전달·감시되도록 한 것이다(34-a). 개발효과성 논의를 기후변화 대응주체들과 공유하고, 기후변화 재원 차원의 혁신이 개발분야 전반에 확산되도록 하였다(34-b).

\section{4. 포스트 부산 이행체제}

부산선언은 앞으로의 이행계획으로 마무리되었다. UN MDGs와 그 이후를 위한 파트너쉽이라는 제목만큼 지속가능한 논의가 되었는지 살펴볼 필요가 있을 것이다.

부산총회에서는 성과점검과 책무성 증진을 위한 프레임워크가 논의되었다. 협력의 효과성과 개발 성과를 개선하는, 진전상황의 점검 및 상호책임성을 위한, 수원국 수요와 우선순위를 기초로 한 프레 임워크에 합의되었다. 이 프레임워크는 수원국이 그 나라의 개발정책과 필요에 맞춰 주도하여야 한 다는 바도 명시되었다. 2012년 6월까지 지표와 목표를 선별·수립하여 부산선언의 진전사항을 점검 해가기로 하였다. 이러한 지표는 개도국 주도의 이니셔티브와 기존에 축적된 원조효과성 논의를 반 영할 것이다. 이러한 조치는 2015년 이후의 포스트 MDGs라는 맥락에서 검토되고, 정기적으로 활동 결과를 발표하게 된다. 개도국의 시각이 개발효과성 논의의 평가와 점검에 반영되어야 한다는 점도 강조되었다. 개도국의 이니셔티브가 개발효과성 제고노력의 영향 평가와 진전사항 점검을 위한 역량 을 보강한다는 전제 하에서 말이다.

다음으로는 원조효과성 고위급포럼 이후의 개발 레짐(regime)에 관한 설명이다. 제 36 항에 따르면, 그것은 (1) 지구적 차원의 대화, 상호학습과 책무성을 위한 포괄적 공간(inclusive space)과 (2) 고위 급회의체의 요소로 이루어진다. 이 파트너쉽은 지역기구와 UN 개발협력포럼(Development Cooperation Forum)도 포함한 것으로 보인다.

새로운 틀로서는 '효과적인 개발협력을 위한 글로벌 파트너십'(Global Partnership for Effective Development Co-operation)이 제시되었다. 이 파트너쉽은 '정치적 수준의 공약 이행을 위한 책무성 을 지원·보장하는 고위급 협의체를 탑재하는 형태로 파악된다. 동시에 포괄적 공간도 제시할 것이 
다. 새로운 파트너쉽은 다양성을 포괄하는 열린 플랫폼으로 규정되고 있다.

글로벌 파트너쉽의 결성을 위한 앞으로의 과제는 다음과 같다. 첫째로 가입조건과 참여기회에 대 한 초안이 2012년 6월까지 합의되어야 한다. 장관급회의로 정기적으로 개최된다는 구상 이외에 나머 지 문제들은 미제로 남겨두었다. 둘째로 원조효과작업반에 2012년 6월 새로운 글로벌 파트너쉽 운영 방안 및 글로벌 모니터링 등이 이루어질 지표와 채널에 관한 합의를 위한 회의에 책임을 부여했다. (같은 때 원조효과작업반은 해산된다는 점을 감안하면 회의개최를 위한 추진력을 보장할 수 있을지 불확실하다.) 끝으로 $\mathrm{OECD}$ 와 $\mathrm{UNDP}$ 를 초대하여 - 아직 합의에 이르지 못한 - 글로벌 파트너쉽의 원활한 기능이 지탱되도록 했다. ${ }^{15)}$

\section{IV. 부산총회 이후 성공적인 개발협력을 위한 의회의 역할}

부산총회 이후 우리 개발협력 분야의 과제는 선진화 문제와 부산총회에 대한 책임성이라고 하겠 다. 이와 관련된 의회의 역할을 비전제시 기능, 법적, 제도적, 정책적, 감독관리 및 성과평가, 그리고 의회외교의 차원별로 제시하고자 한다.

\section{1. 비전 제시}

국회는 부산총회에서 제시된 개발 파트너의 비전을 우리 개발협력의 비전에 반영시켜야 할 것이 다. 한국의 개발협력은 '고기 잡는 법을 나누는' 개발협력이 되어야 한다. 부산에서 논의된 개발 문제 는 소모적 원조가 아닌 빈곤국의 자립을 지향하고 있다. 교육을 통해 산업화를 달성하고 빈곤을 퇴치 한 우리나라의 비결이 개도국의 지속가능한 발전에 기여할 것이다.

국제사회는 개도국들에게 잡은 고기 나눠줄 것이 아니라 고기를 잡는 법을 나눌 수 있어야만 한다 는 문제의식이 커져가고 있다. 1960년 이후부터 2010년까지 DAC회원국이 시행한 ODA총액이 약 2 조불에 달하지만, 최빈개도국의 숫자는 1970 년대의 2 배로 늘어났다. 약 8 억명의 사람들은 여전히 굶

15) 김태균은 부산선언의 한계를 지적하고 있는데 그 중에서 주목되는 것은 다음과 같다. (1) 아크라 행동계획의 원조 비구 속화와 관련된 내용이 부재하다. 이것은 BOD 2차 초안에 반영되어 있었으나 최종안에서는 제외되어 있다. (2) 시민단체 의 제안인 인권, 민주적 주인의식, 투명성, 정책의 일관성 등은 부분적으로만 논의되고 적극적으로 파트너쉽에 반영되 지 못했다. (3) 우리 정부가 새롭게 제안한 양성평등, 녹색개발 모두 명시적으로 반영되지 못했다. (4) 파트너쉽의 명칭이 "개발효과성을 위한 부산파트너쉽(Busan Partnership for Development Effectiveness)"에서 “효과적 개발협력을 위한 부산파트너쉽(Busan Partnership for Effective Development Cooperation)"으로 바뀌어 그 위상을 의심하게 한다는 등 의 내용이다. 김태균, "부산총회 이후 국제개발원조레짐의 변화와 한국(EAI 논평 제23호)"(EAI, 2011)를 참조하였음. 
주림 속에 잠을 청하고, 전 세계 25 억명은 기본적 위생시설 없이 생활한다. 또한 12 억명의 인구는 수 자원을 안전하게 사용할 수 없는 생활조건에서 살아간다. UN MDGs 체제 하에서 빈곤문제가 일부 완화되어 왔지만, 빈곤을 낳는 근본적 요인은 해소되지 못한 상태이다. 그에 따라 빈곤층이 원조로부 터 졸업할 수 있도록 도와주기 위한 성장과 개발의 개념이 주목을 받고 있다. 2015년 UN MDGs 이 후의 시대를 대비하고 있는 것으로서 개발의 비전은 한동안 개발협력의 장을 주도하게 될 전망이다. 이러한 비전 하에서 부산총회에서도 개발효과성의 문제가 논의된 것이다. 원조고위급포럼(HLF)에서 다루어온 원조효과성의 문제 역시 개발이라는 목표 하에서 재편되어 가고 있음을 보여준다.

한국은 개발협력의 새로운 부산총회의 비전을 세계에 제시할 의무가 있다. 한국은 가장 최근의 시 기에 발전을 이룬 나라이자 $\mathrm{DAC}$ 회원국이다. 개도국과 선진공여국 모두와 개발협력의 비전을 나눌 수 있다는 것이다. 우리나라는 대외원조를 제 1,2 차 경제개발계획의 추진 및 중화학공업 육성을 위해 적극적으로 활용하였다. 대외국제경제협의체도 제안해서 원조채널을 효율적으로 관리하였다. 이러 한 경험은 부산선언이 언급하는 주인의식 및 수원국 주도 조정제도 등을 40 여년 앞서 보여주고 있다 고 할 것이다. 이러한 한국이 새로운 비전을 구체화하여 개도국의 빈곤퇴치에 앞장서지 않는다면, 어 느 나라가 이러한 역할을 맡을 수 있을까.

한국의 개발비전 제시는 개도국외교, 통일대비, 국제안보 차원에서 우리나라의 국익에도 기여한 다. 한국이 경제적으로는 성장했지만 국제사회에서 설 땅(relevance)이 부족하다는 지적이 제기되어 왔다. 중앙아시아, 서남아시아, 동남아시아, 중남미, 아프리카, 중동 지역의 개도국과의 친선관계를 확대하기 위한 소프트파워가 절실하다. 그 한 방법이 인간중심의 개발협력이다. 경제적 이익만 쫓는 외교에는 한계가 있기에 개도국을 개발의 길로 함께 이끌어가야 한다. 한편, 민족의 최대과제인 통일 문제를 염두에 둘 때에도 한국 개발협력의 선도적 비전의 발전이 필요하다. 개발협력 경험은 추후의 대북개발에 활용될 수 있으며, 저소득국가, 취약국가, 체제전환국에 대한 원조 원칙과 실제 등은 우 리에게 시사점을 제공해주고 있다. 국제적 원조방식(Modality)를 염두에 둔 북한에 대한 국별지원전 략 제시, 컨소시엄 등 민간기구, 시민단체 등과의 효과적인 연대체제가 필요하다는 것이다. ${ }^{16)}$ 나아 가 효과적인개발협력을 위한 글로벌 파트너쉽은 남북경제공동체 형성의 단계에서 우리의 재정적 부 담을 덜어줄 수 있는 플랫폼이 될 수도 있다. 우리가 북한 비핵화 이후의 국면에 대비하여 우리는 국 제개발원조레짐의 운전대에 손을 얹어놓을 수 있어야 한다는 것이다. 북한도 어느 한 나라에 의존하 는 발전과 국제적 규범에 의한 개발 중 후자를 선호할 것이다. 세계적으로도 통일한국이 '홍익인간 (弘益人間)'의 나라가 될 것임을 인식시켜야 한다. 이처럼 개도국의 발전에 대한 기여가 국익에도 기 여한다는 관점에서 우리는 개발협력의 미래비전을 적극적으로 제시해갈 필요가 있다.

16) 전승훈, 정연승, 손광주, 김소원, 『개발협력 경험의 대북지원 활용방안』(한국국제협력단, 2010)을 참조하였음. 


\section{2. 법적 지원}

국제개발기본법 시행 이후의 경과, 그리고 부산총회의 정치선언문을 참고하면서 기본법의 보완방 향에 대한 이해를 수렴해갈 필요가 있다. 2009년 12월 29일 국제개발기본법이 제정되었다. 국제개발

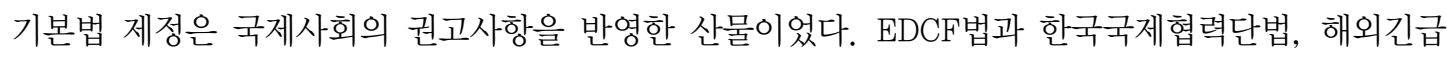
구호에 관한 법률 등을 포괄하는 법제가 없다는 견해를 $\mathrm{DAC}$ 는 표시했던 것이다. 국회도 통합적 원조 시스템의 법적 기초를 만들고, 개발협력정책의 목적을 주관하는 일원적 위원회를 설립해야 한다는 권고 사항을 감안하였다. 그에 따라 송민순 의원, 배영식 의원, 진영 의원, 김부겸 의원, 이미경 의원 등은 각자의 제정안 초안을 제출했었다. 이러한 개정안과 관계부처의 의견을 수렴하여 기본법이 마 련된 것이다.

먼저 발전경험 경험전수 사업의 중요성이 대두되고 있는 만큼, 관계 규정이 마련될 필요가 있다. 제정당시 경험발전 전수사업에 관한 총괄기관의 지정 여부 및 담당기관에 대한 이견이 첨예하였다. 그 결과 경험전수사업을 위한 규정이 명시되지는 않은 것이다. 부산선언에는 (남남협력의 유효성을 인정하는 차원에서) 발전경험과 지식의 공유가 갖는 중요성이 언급되고 있다. 또한 경험전수는 우리 나라가 실질적으로 수원국의 발전에 기여할 잠재성이 큰 분야이다. 원조총액이 GNI의 $0.12 \%$, 일본 의 $1 / 10$ 에 불과한 우리나라로서는 수원국의 발전에 효과적으로 기여할 수 있는 길을 찾아야 한다. 개 도국 발전의 중심적 가치를 유념하면서, 우리나라의 개발경험 전수를 위한 조항을 마련하도록 해야 하지 않을까 하는 생각이다. 제 11 조 시행계획의 수립 규정만이 아니라 제 8 조 기본계획의 수립 등의 규정을 통해 발전경험 공유 사업을 위한 계획이 포함되도록 하는 형태로 고려해볼 수 있다.

경험전수를 위해 전문성과 특수성에 입각한 협력이 보장되어야 한다. 현재 기재부가 KSP사업을, 교과부와 복지부는 원조모델 개발을 진행 중이지만, 무상원조 사업 및 외교활동과 별도로 이루어지 는 한계가 있다. 한편, 부산선언 제 23 항 $b$ 호에 따르면 참가국들은 수원국 현지의 원조정보시스템 등 을 구축하기로 하였다. 이러한 수원국 현지의 원조정보 역시 맞춤형 개발모델 개발에 걸림없이 투입 되어야 할 것이다.

둘째로는 국제사회의 공약사항에 대한 진행상황을 국회가 평가하는 문제이다. 기본법 제 13 조에 따 르면 국제개발협력위원회는 국제개발협력의 사업성과에 대해 추진실적을 매년 6 월 30 일까지 국회에 보고하게 되어 있다. ODA선진화 방안은 ODA규모를 2015년까지 GNI대비 $0.25 \%$ 로, 비구속성 비율 을 역시 2015년까지 75\% 수준으로 확대한다는 내용을 담고 있다. 부산총회에서 참가국들은 2013년 까지 3 5개년의 연동 예산안 또는 아크라에서 합의된 바 있는 이행계획을 제출하게 되어 있으며, 같 은 해까지 수원국 주도의 조정 제도를 적극적으로 이행하기로 하였다. 국제사회의 권고에 기반한 
$\mathrm{ODA}$ 규모 등의 개선과 아울러 부산총회의 공약사항 등에 대한 적실성 있는 보고가 이루어져야 한다.

이러한 의미에서 개발협력 분야 전반에 대한 국회의 모니터링 체제도 개선될 필요가 있다. 미국의 경우 매년 국가별 대외원조활동에 대한 보고를 받고 있으며, 청문회 등을 통해서도 대외원조 정책을 감독하고 있는 반면, 우리나라의 경우 기본법 상으로는 통계자료를 제출받을 수 있는 권리 정도만 갖 는다는 점이 지적되어 왔다. ${ }^{17)}$ 또한 유상 원조기관은 기획재정위원회에, 무상 원조기관은 외교통상 통일위원회에 각기 소속되어 있는 상황에서, 우리나라의 개발협력 활동 전반이 개도국 개발의 과제 에 기여한 정도 등을 검토하기 어렵다. 수개 상임위에 걸쳐 있는 원조활동을 평가- 개선 하기 위한 국 회 차원의 적절한 프레임 마련도 필요할 것이다.

부산총회 이후의 개발협력 관계법을 논함에 있어 빈곤퇴치기여금의 시행기간 연장문제도 빼놓을 수 없다. 부산선언 제 10 항은 다양한 개발재원의 활용도 제고, 신규 도입 등의 문제를 언급한다. 빈곤 퇴치기금은 2007년 9월 도입된 혁신재원이다. 2005년 최빈개도국의 MDGs 달성을 위한 개발재원 발굴 노력을 촉구하는 뉴욕선언문이 채택되었었다. 빈곤퇴치기여금은 뉴욕선언문의 혁신재원 발굴 필요성을 받아들여 도입된 것이라 하겠다. 2007년부터 2010년까지 약 492억원이 조성되었으며, 주 로 사하라 이남 아프리카 지역의 영유아 보건의료 사업, 뇌수막염·말라이 퇴치 등을 위해 지출되었 다. 이 빈곤퇴치기여금은 한국국제협력단법 상 5 년동안만 한시적으로 도입되었기 때문에, 2012 년 9 월이면 시행이 종료될 예정이다. 홍정욱 의원 등이 기금의 시한을 연장하는 개정안을 내놓았지만, 아 직 논의되지 못하고 있다.

\section{3. 제도적 지원}

제도적 고려사항으로서 우리나라 개발협력의 분절화 문제를 빼놓을 수 없다. 원조체계가 유/무상 으로 크게 이원화되어 있고, 32 개 부처 및 기관이 1,073 개의 사업을 추진하고 있을 정도로 분절화 수 준이 높다. 한국국제협력단과 수출입은행 이외에도 한국은행, 교육과학부, 보건복지부, 행정안전부, 농림부, 환경부, 국방부까지 각자의 대외협력 사업을 진행 중인 것이다. 원조전담 기관 이외의 부처 및 기관이 시행하는 원조활동이 전체 원조액의 약 $38 \%$ 를 차지할 정도이다. 우리는 부산선언 제 25 항 및 2008년 OECD DAC의 권고사항을 유념하면서 분절화 개선을 위한 노력을 넓혀가야 할 것이다.

우리나라의 현재 개발협력 체계의 급격한 통합이 어렵다고 본다면, 우선 일부 기능부터 통합하는 것이 중요하다. 앞서 ODA 선진화방안은 그 해답을 유무상 양기관의 국가전략수립에 관한 협의, 사업 발굴 및 선정에 관한 각 전담기관과 개별부처 간의 협의를 위한 절차를 마련하는 데에서 찾았다. 이

17) 유웅조, "부산 '세계개발원조총회'와 ODA 정책 개선과제(이슈와 논점 제 333호)" (국회 입법조사처, 2011). 
러한 접근방식은 절차를 중심에 둔 것으로 오랫동안 굳어져 온 원조분절화 현상을 해소하기에는 한 계가 있을 수 있다. 정책일관성 검토 및 사업평가 부문에서 유무상 원조기관의 기능을 통합하는 방안 에 시선을 돌리게 되는 것이다. 독일의 경우 유무상 이원적 원조시스템의 한계를 극복하기 위해 독립 적인 전문연구소(GDI, German Development Institut)를 설립하였다. GDI는 독일 개발협력의 효과 성과 정책일관성 등에 대한 분석 및 연구를 진행하고 있다. 네덜란드는 외교부에 개발협력업무가 집 중되어 있는 원조체계를 가지고 있지만 정책일관성 기구(PCU, Policy Coherence Unit)를 설립해 다 른 부처의 정책일관성 및 성과에 대한 감독을 시행하고 있다. 18) 이를 우리나라에 적용한다면, 국제 개발협력위원회 산하의, 혹은 독립적인 정책일관성 제고/사업평가 기구를 두어서 점진적으로 분절화 의 부작용을 낮추어가기 위한 노력을 시도해볼 수도 있을 것이다.

특히 사업평가 및 모니터링 차원에서 통합적 기능의 구축을 우선하여 도입해볼 필요가 있다. 부패 없는 원조의 집행 및 전달체계가 수원국의 지속가능한 개발에 필수적인 요소라고 할 것이기 때문이다.

부산선언에 제시된 글로벌 파트너쉽을 실질적으로 지원하고, 실질적인 개도국의 지속가능한 발전 을 지지하기 위하여 국제적 수준의 기구를 수립하는 방안도 상상해볼 수 있다. 이를 통해 우리의 개 발과정에서 기여한 KDI와 같은 조직의 서비스를 수원국들에게 제공하는 것이다.

이 연장선에서 개발협력 기관의 대외협력 기능도 확대되어야 한다. 부산선언은 국제개발원조레짐의 복잡성을 인정하면서, 열린 포럼을 지향하고 있다. 따라서 협력해야 할 대상이 일부 선진공여국과 수원 국만이 아니라 기업, 노조, 자선펀드, 국내외 $\mathrm{NGO}$, 시민사회 및 의회 등으로 크게 확대될 전망이다. 남남협력에 참가하는 중진 개도국과의 협력관계 구축도 포스트 부산체제에서는 중요한 과제가 될 것이 다. 다양한 행위자와의 연락망을 다른 손에 잡고 복잡한 파트너쉽을 이끌어갈 능력을 길러야 한다.

\section{4. 정책적 지원}

가장 중요한 것은 한국의 맞춤형 개발모델의 제시이다. 수원국들이 참고할 수 있는 참고서를 제시 할 수 있어야 한다. 우리나라의 산업발전 과정, 그 과정에서 새마을운동과 교육이 가졌던 중요성을 구체적 사례를 통해 설명하고 수원국의 사정에 응용할 수 있도록 도와야 할 것이다. 이 점에서 지속 가능한 발전을 위한 모델의 제시가 중요하다. 한국 경제 및 사회의 발전사에 대한 연구와 정리작업을 정책적으로 진흥할 필요가 있을 것이다.

또한 그 시행과정에 WFK 봉사단 사업이 적절히 연계될 수 있는 방안도 개발되어야 한다. 경제개 발의 경험을 몸에 새기고 있는 시니어봉사단의 파견을 확대하는 문제를 우선 검토할 필요가 있다. 우

18) 김은미, 김지현, 『한국 원조체제의 분절이 원조효과성에 미치는 영향 및 개선방안 (한국국제협력단, 2009), pp. 78-84. 
리나라에서는 과거의 기술도 개도국의 산업환경에서는 고급기술에 속할 수 있다. 자동차 정비, 봉제 등 기술분야의 은퇴자가 해외봉사단에 참가할 경우 수원국 입장에서의 유용성이 매우 클 것이므로 이들을 교수요원의 지위 등으로 파견해 수원국의 인재개발에 기여하도록 하는 방안을 고려해야한다.

우리는 부산총회 개최국으로 미해결 과제들을 논의하기 위한 후속대화의 안정적인 개최를 촉구해 가야 한다. 일부 준비회의를 우리가 유치하는 것도 방법이다. 부산선언에는 내년 6월 혹은 2013년까 지 합의되어야 하는 문제들이 여러 가지 존재한다. 먼저 제 18 항 e호에 따라 비구속성 달성계획은 2012년까지 점검되어야 한다. 본래 부산선언 초안에는 2013년까지 원조의 비구속화 비율을 $100 \%$ 로 한다는 표현이 들어 있었다. 그러나 이것이 삭제되고, 비구속화 목표도 제시되지 못하자 관련 NGO 및 시민단체에서는 비판적 시각을 보낸 바 있다. 이러한 시각을 해소하기 위해서라도 우리나라의 책 임있는 태도가 촉구되어야 할 것이다. 2012년 6월까지 부산선언의 이행지표 수립, 글로벌 파트너쉽 운영방안, 글로벌 모니터링 지표와 채널에 대한 합의가 마련되어야 한다. 또 2012년 12월까지 정보 공개 표준방식과 다자협력 활용에 관한 가이드라인 및 원조소외국 지원 방향이 합의되지 않으면 안 된다. 우리가 책임있는 공여국의 입지를 다지기 위해서는 이와 같은 2012년 내의 관계일정 수립을 위해 최대한 노력해가야 할 것이다.

우리 원조기관과 $\mathrm{NGO}$ 및 기업과의 역할분담 강화도 시급한 과제이다. 부산선언은 $\mathrm{NGO}$ 등을 포 괄하는 파트너쉽을 강조하고 있다. $\mathrm{ODA}$ 선진화방안에서도 정부와 $\mathrm{NGO}$ 간의 연계사업, 민관협력 사 업 $(\mathrm{PPP})$ 사업의 확대 필요성이 지적되어 왔다. 이는 부산선언과 $\mathrm{ODA}$ 선진화 방안의 지적이 수렴되는 부분이라고 하겠다.

$\mathrm{KOICA}$ 의 경우에는 NGO 및 민관협력 사업이 초보적이나마 자리를 잡아가고 있는 모습을 보이고 있 다. 2010년 협력사업비의 $2 \% 78$ 억원에 불과하던 NGO와의 연계사업 규모가 2011년 171억원, 2012년 376 억원으로 증대되고 있는 것은 긍정적 현상이다. 기업과의 민관협력 사업도 2010 년에야 처음으로 시 작되었지만 2011년 40 억원 정도의 예산이 확보되어 시행되었다. 다만 2012년 사업규모는 예년과 거의 동일한 모습을 보여주고 있다. $\mathrm{ODA}$ 선진화 방안은 이러한 $\mathrm{NGO}$ 및 기업간의 역할 분담이 원조효과를 제 고시킬 수 있다고 평가하고, $\mathrm{NGO}$ 및 기업과의 협력을 강화하기 위한 세부방안을 외교부로 하여금 마련 하도록 하고 있다. 그 하나로서 무상원조기관이 민관협력 예산을 2015년까지 10 배 늘리도록 하였다.

이와 함께 유상원조 기관의 PPP 활성화 방안도 개발해가야 한다. 이는 개발을 위한 민간재원 조달 을 촉진하기 위해 검토되어야 할 문제이다. 부산선언 제 32 항 c호에서 지적된 것처럼 공동의 개발 목 표를 달성하는데 민간 재원을 동원할 수 있는 금융체계를 더욱 발전시켜가야 할 필요가 있다. 우리의 $\mathrm{ODA}$ 선진화방안도 유상협력을 통한 민자사업이 도로, 철도, 항만 등 무역분야 개발과 대형 인프라 개 
발에 적합한 재원확충 방식이라고 제시하고 있다.

나아가 NGO를 실질적인 개발협력의 파트너로 인정해가는 것이 매우 중요하다. 부산선언의 가장 중요한 성과 중 하나가 민간주체들에게 열려 있는 열린 포럼 형태의 파트너쉽을 제시한 것이다. 아울 러 $\mathrm{ODA}$ 선진화 방안도 선진국에 비해 우리의 $\mathrm{NGO}$-정부간 협력이 미흡함을 지적하면서 상시적인 협 력채널을 구축하는 방안을 제시하고 있다. 다양한 민간 개발주체들과 네트워킹할 수 있는 채널을 만 드는 것은 필수적인 과제이다.

이외에도 투명성 강화와 특혜관세 등 여러 과제를 언급해볼 수 있다. 국제 원조 투명성 이니셔티브 (International Aid Transparency Initiative) 등의 부산선언 미해결 과제에 대해서도 참여방안을 적극적 으로 모색할 필요가 있다. 이번 총회에서 영국 등은 투명성 강화를 위한 노력을 촉구했었으나 선언문에는 반영되지 못한 내용이다. 최빈개도국에 대한 특혜관세도 전향적으로 검토해가야 할 것이다. 우리나라는 2008년 최빈개도국을 위한 특혜관세 범위를 큰 폭으로 확대하였으나, 이 나라들의 여건상 수출확대에는 한계가 있다. 이에 따라 원산지 규정을 단순화, 완화하는 문제의 필요성이 제기되고 있는 것이다. ${ }^{19)}$

\section{5. 감독활동}

의회는 국정감사 등을 통해 대외원조의 투명성과 효과성을 제고하고 있다. 최근 수년간 국정감사 지적사항을 보면, 모니터링 활성화, 타당성 조사에 관여한 업체에 대한 입찰 참여제한 촉구, 완공점 검 처리기간의 단축, 사후평가 미실시 사례에 대한 경고 등 다양한 문제점이 지적되어 왔다. 이러한 감사활동은 현장에서의 규정준수, 불합리한 제도의 개선 등을 통해 대외원조 활동을 투명하게 하고 있다. 예산 집행/결산 심사 등을 통해서도 재정규율 준수, 위법성 여부, 낭비요소, 국회의 지적사항 반영여부, 중복추진 여부 등을 검토함으로써 원조활동의 투명성을 점검한다.

아울러 의회는 원조선진화 등의 과제달성을 지속적으로 촉구해왔다. 개발협력을 위한 민관협력 사 업 발굴 요구, ODA 대국민 홍보 방안 점검(이상 2008년), 아프리카에 대한 원조비율 제고, 해외봉사 단 안전대책 강구 촉구(이상 2009년), 무상원조 총괄기능 일원화, ODA 규모 확대(이상 2010년) 등을 지적하면서 불합리한 제도의 개선, 시야형성 등 역할을 수행해 왔다.

$19)$ 조미진, 김민성, 『최빈개도국에 대한 특혜관세제도 활용 현황 및 과제(무역투자연구시리즈 10-02』(대외경제정책연구 원, 2010)을 참조하였음. 


\section{6. 성과평가와 대국민 홍보}

국회는 우리 개발협력의 성과 평가에 있어 그 나라의 개발에 얼마나 기여했는지를 중시하여 부산 총회의 정신과 수원국 개발의 목표가 충실히 실현되도록 지원해가야 하겠다. 개발 패러다임의 전환 이 국회의 원조기관 성과 평가에도 적용되지 않는다면, 국제적 차원과 국내적 차원 간의 괴리만 커지 는 결과가 될 것이다. 이러한 전환이 안정적으로 이루어지기 위해서는 개발협력 전담기관과 국회 예 산정책처, 입법조사처 간의 협의도 주효하리라고 본다.

또한 국내적으로 부족한 ODA인지 제고를 위한 국회의 역할이 필요하다. 2005년 대외경제정책연 구원의 여론조사에 따르면, 우리나라의 국민들이 대외원조에 대한 찬성여론은 $62.3 \%$ 로 높은 반면, 원조활동 내용에 대한 인지도는 $37.1 \%$ 에 불과했다. DAC 역시 한국 국민의 대외원조에 대한 인지도 가 낮은 편이고 합의도 불충분하다고 지적한 바 있었다.

대국민 홍보 차원에서 기성세대에게 ODA를 알릴 이미지도 필요하다. 개발협력에 대한 세대차이가 존재하기 때문이다. 한비야 세대라고 불리우는 20 대는 개도국 원조에 대한 긍정적인 이미지를 가지 고 있으나, 그 윗세대가 개발협력에 부여하는 중요성은 그리 크지 않다. 최근 공영방송에서 국제협력 단에 대한 특집프로그램을 제작 방영하는 등 $\mathrm{ODA}$ 인지 제고를 위한 노력에 동참하고 있는 것은 일견 긍정적인 현상이지만, 특정 연령대·계층의 국민들에게만 메시지가 전달되는 데 그칠 수 있다. 따라 서 60-70년대 개발연대의 경험과 현재의 공여활동을 연결짓는 이미지를 만들어가야 한다는 것이다.

\section{7. 외국 의회와의 협력}

개발협력을 위한 민주적 주인의식의 고취를 위해서 의회 간의 협력이 중요하다. 부선선언 제 21 항은 의회가 개발과정을 적절히 감시할 수 있도록 그 역량강화를 지원하자는 내용을 담고 있다. 그 취지는 수 원국의 의회가 그 나라의 지속가능한 개발이라는 목표를 지향하도록 하자는 것으로 미루어볼 수 있다. 예산지원(budget support)을 받는 수원국의 경우, 의회에서부터 예산형태의 ODA를 목적에 부합하도록 사용해야 하기 때문이다. 이와 관련해서 국회가 할 수 있는 활동은 의원친선협회를 통해서 상대국의 자 립의지를 북돋고 개발 이니셔티브를 지원해주는 일이 될 것이다. 현재 국회에는 총 97 개의 의원친선협 회가 활동 중이다. 각국을 담당한 의원그룹은 상대국의 의회 내의 한국담당 의원그룹과 교류· 소통을 진 행한다. 이러한 의원친선관계를 맺고 있는 97 개국 중 18 개국이 유무상 통합중점협력국이다. 특히 이 18 개국 중에서 네 나라는 최빈개도국이기도 하다. 국회는 18 개 나라들, 좁게는 4 개 나라들과의 의회교류 를 통해서 상대방의 민주적 주인의식 고취를 지원하고, 의정역량 강화 차원의 애로사항을 수렴할 수 있 는 잠재력이 있다. 이러한 잠재성의 실현을 위해서는 원조기관들의 긴밀한 지원이 뒷받침될 필요가 있 
을 것이다. 또한 국회 차원에서도 개발협력 분야에 대한 소양을 다지기 위한 노력이 필요하다.

나아가 원조기관도 부산총회 이후의 맥락에서 통합 중점협력국이자 최빈개도국인 나라들이 의정역

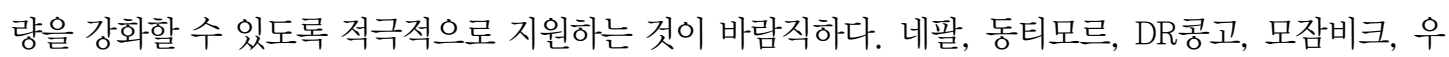
간다, 솔로몬군도는 최빈개도국에 중점협력국이지만 우리나라와의 의회간 친선관계를 맺고 있지 못하 다. 장기적으로 이러한 나라들에 대한 의회간 친선관계 수립 등이 검토되어야 할 필요가 있을 것이다.

또한 국제의회외교 차원에서도 개발협력에 관한 반부패 및 투명성 제고를 위해 노력할 수 있겠다. 2010년 스위스에서 열린 국제의회연맹(IPU)에서는 정치제도 차원에서 반부패 문제를 논의하였었다. 이러한 논의는 일반적인 뇌물 및 부패 등의 척결에 관해서도 연결될 수 있을 것이다. 아시아의회외교 차원에서도 개발효과성을 위한 논의 등을 안건으로 제시하는 노력도 생각해볼 수 있다. 이러한 국제의 회외교는 개발협력 자체의 비전 전파에는 물론 굿거버넌스 환경의 조성에도 기여할 수 있을 것이다.

\section{V. 결론}

이상에서 부산총회 결과와 국회의 역할에 대하여 논하였다. 11 월 29 일부터 12 월 1 일까지 부산에서 개최된 세계개발원조총회에서 국제사회는 개도국의 실질적인 개발을 중심에 놓고 원조의 효과성에 대 하여 논의하였다. 국제개발레짐의 패러다임이 원조에서 개발로 전환되고 있는 것이다. 한국 개발협력 분야가 지향해야 할 목표도 그와 함께 변화하는 중이다. 이 속에서 우리나라가 경제발전 과정에서 겪 은 성공과 실패의 경험을 기초로 수원국 중심의 개발협력정책을 행하는 일이 보다 중요해지고 있다.

본고는 제 2 장부터 제4장까지 한국과 개발협력, 부산총회 결과문서, 그리고 부산총회 이후의 성공 적인 개발협력을 위한 의회의 역할을 검토하였다. 먼저 제 2 장에서는 한국과 국제 개발협력의 관계를 정리하였다. 수원국이었던 우리나라가 공여국으로서 개발협력 분야를 새롭게 접해가고 있는 가운데, 2000 년 이래 융합적 노력을 강화해온 국제개발레짐은 다양한 개발주체와 개발의제의 등장으로 복잡 성의 증가라는 새로운 도전에 직면하고 있다. 한국의 원조분야는 그 후발주자로서 유상원조는 교통, 수자원, 에너지, 무상분야는 보건, 교육, 행정분야를 중심으로 개도국의 발전을 지원해가고 있다. 이 러한 국제사회와 개별국가들의 노력에도 불구하고 빈곤퇴치 실적은 미미한 가운데 수원국의 자립의 지와 거버넌스 발전, 그리고 공여국의 태도전환이 요청되고 있다. 원조도 개발이라는 목표 하에서 개 발을 촉진하는 역할에 무게를 두어야 한다는 점도 지적된다.

제 3 장에서는 부산선언의 내용을 독자들에게 소개하였다. 부산세계개발원조총회의 정치선언문은 
모두 36항으로 구성되었으며, 신흥개도국과 $\mathrm{NGO}$ 등 새로운 주체를 포괄하는 글로벌 파트너쉽의 기 초를 제시하였다. 또한 원조에 대한 패러다임의 전환도 수반되었다. 개발목표를 위해 원조는 물론 그 외의 다양한 개발재원의 활성화 과제가 제시된 것이다. 기존의 원조효과성 제고를 위해서는 주인의 식, 성과 및 책임성 강화, 투명성 및 책임성, 취약국가 및 저발전 도서국에 대한 지원이 요청되었으 며, 개발효과성 확보를 위한 수원국 주도의 프레임워크, 남남협력 및 삼각협력, 민간분야, 부패 및 불법자금 대처노력도 강조되었다. 이어 이러한 공약을 이행하기 위한 글로벌 파트너쉽을 위한 기초 를 2012년 6월까지 마련하도록 하였다.

제4장에서는 성공적인 개발협력을 위해 의회가 역할을 탐색하여 법, 제도, 정책 등 다차원에 걸쳐 제시하였다. 의회는 고기 잡는 법을 나누는 원조라는 우리 원조의 비전을 제시해가야 한다. 법적 차 원에서는 기본법을 통한 발전경험 공유사업 강조 및 명확화, 평가 강화 등을 위한 개정노력이 고려될 수 있겠다. 제도상으로는 우리나라는 분절화 완화와 더불어 다양한 개발주체와의 협력기능이 강화되 어야 한다. 분절화와 관련해서는 유무상기관의 일부 기능부터 통합적으로 제공하는 독일의 GDI를 모 델로 삼을 수 있을 것이다. 개도국의 발전을 지원하는 서비스도 제공해야 하고, 대외협력 기능도 강 화되어야 한다. 이러한 제도변화 중 일부는 연계되어 진행될 수도 있을 것이며, 한국적 개발모델의 제시, 후속대화 개최 및 파트너 구축의 책임 수행, NGO 및 민관협력의 강화를 위한 노력을 강조해가 야 한다. 국회는 국정감사, 예결산 등의 감독기능, 다양한 계층에 대한 홍보 기능을 통해 효과적 개 발을 위한 $\mathrm{ODA}$ 선진화를 지원하고, 외국 의회와의 협력을 통해 수원국 의회의 개발노력을 지지해나 갈 것이다.

부산선언의 4대원칙에 대해 인식하면서 이행 및 제도발전을 지원해가야 한다고 본다. 개발 우선과 제에 대한 개도국들의 주인의식 고취, 결과중심 사업추진, 포괄적인 개발 파트너십 형성, 투명성과 상호 책무성 강조 등 부산선언의 4 대 원칙은 우리 개발협력 사업에도 반영되어야 할 것이고, 관련 법 중 개선 필요사항은 적극 지원해나갈 것이다. 


\section{참고문헌}

\section{1. 국내문헌}

권혁주, “취약국가의 이해 : INCAF와 국제협력 기구의 논의를 중심으로," 국제개발협력』 2010년 제3호, pp. 46-65.

권율, 박수경, 『중국의 대외원조정책과 추진과제』(대외경제정책연구원, 2010).

글렌 허버드, 윌리엄 던컨 지음, 조혜연 옮김, 『원조의 덫』(비지니스맵, 2010).

김영철, “중동의 $\mathrm{ODA}$ (공적개발원조) 정책과 방향 : 터키 $\mathrm{ODA}$ 를 중심으로," 국제개발협력』 2011년 제3호, pp. 67-90.

김은미, 김지현, 『한국 원조체제의 분절이 원조효과성에 미치는 영향 및 개선방안』한국국 제협력단, 2009).

김태균, “부산총회 이후 국제개발원조레짐의 변화와 한국(EAI 논평 제 23 호)"(동아시아연구 원, 2011).

유웅조, “부산 '세계개발원조총회'와 ODA 정책 개선과제(이슈와 논점 제 333호)"(국회 입법 조사처, 2011).

이천우, “국제 공적개발원조의 신조류와 한국의 ODA정책," 『산업정책연구』 제 24 권, 제 2 호, pp. 777-808.

전승훈, 정연승, 손광주, 김소원, 『개발협력 경험의 대북지원 활용방안』(한국국제협력단, 2010).

정우진, 『한국형 개발협력 모델 : 한국적 경험과 비교우위에 근거한 섹터별 프로그램』(한국 국제협력단, 2010).

제프리 D. 삭스 지음, 김현구 옮김, 『빈곤의 종말』(21세기북스, 2000).

조미진, 김민성, 『최빈개도국에 대한 특혜관세제도 활용 현황 및 과제(무역투자연구시리즈 10-02』(대외경제정책연구원, 2010).

주동주, 『국제개발과 국제원조』(시나리오친구들, 2011).

주OECD 대표부, 『공적개발원조(ODA) 정책에 대한 $\mathrm{OECD}$ 의 논의동향(OECD 경제정보 2009-2)』

(주OECD 대표부, 2009).

한국국제협력단, 『한국에 대한 개발원조와 협력 : 우리나라의 수원 규모와 분야, 효과사례 등에 관한 조사연구』(한국국제협력단, 2004).

한국국제협력단, 『한국국제협력단 20년』(한국국제협력단, 2011). 


\section{2. 국외문헌}

Dambisa Moyo, Dead Aid: why Aid is not working and how there is a better way for Africa(New York : Farrar, Straus and Giroux, 2009).

Homi Kharas, Koji Makino, Woojin Jung (eds.), Catalyzing Development: A New Vision For Aid(Washington D.C.: The Brookings Institution, 2011). UNCTAD, “The Least Developed Countries Report 2011”(UN, 2011). 